\title{
Eriocaulaceae of rice fields of Bilaspur in Chhattisgarh
}

\author{
Snehal Moghe', Veenapani Dubey ${ }^{2}$ \\ ${ }^{1}$ Department of Botany, Government Bilasa Girls PG College, Bilaspur, Chhattisgarh, India, ${ }^{2}$ Department of Botany, C.M. Dubey \\ College, Bilaspur, Chhattisgarh, India
}

Received: 12.04 .2017

Accepted: 05.07 .2017

Published: 20.07.2017

*Address for correspondence:

Dr. Veenapani Dubey,

Department of Botany,

C. M. Dubey College,

Bilaspur, E-mail: dubey.

veenapani@gmail.com.

\begin{abstract}
During our field visits in rice fields of Bilaspur, Chhattisgarh, we found 3 species of Eriocaulon belonging to family Eriocaulaceae, commonly known as "Pipewort" family (Haines, 1921). Although it was not very common, it's interesting and complicated morphological features made us to view this species from a different angle. These have been discussed in this paper.
\end{abstract}

KEY WORDS: Eriocaulon, Eriocaulon quinquangular, pipeworts, rice field

\section{INTRODUCTION}

In India, the family Eriocaulaceae is represented by a single genus Eriocaulon Linn. The family is considered as the most difficult due to minute floral parts of the plants. The species are difficult to diagnose due to the uniformity in the vegetative parts accompanied by a surprising amount of disparity in the floral parts; (Fyson, 1921). According to Hooker (1893), the "Indian species of Eriocaulon are the most difficult of classification, presenting no good sectional characters." This seems to be reason why the plants of this group have not been described in major floras and are least used for other fields of botanical studies. Ruhland (1903) had written a monograph on "Eriocaulon." For Indian plants, the works of Hooker (1893) and Fyson (1919-1922) are dependable for determining the species. Ruhland (1903), in his monograph, recognized 47 species from India. Fyson (1919-1922) described 51 species and a few varieties for "British India." Further details were made available by Moldenke (1971, 1980, 1982, 1982a, 1983, and 1985). Nair(1987) have observed the taxonomic significance of seed coat morphology in identifying the species of Eriocaulon. Murti and Panigrahi(1999) have described the family in Flora of Bilaspur district, Madya Pradesh. Ansari and Balakrishnan(2009) have described 80 species of Eriocaulon recognized after analytical study of specimens and review of literature. Sharma et al. (1985) have reported Eriocaulon setaceum L., Eriocaulon quinquangular L., and Eriocaulon sollyanum as common emergent hydrophytes in Raipur of then Madhya Pradesh. However, Khanna et al. (2009) have a mention of 5 species of Eriocaulon in "Floristic diversity of Chhattisgarh."

According to Ansari and Balakrishnan (2009), E. setaceum L. is restricted to west part of peninsular India and Sri Lanka. They say that E. setaceum (sync to Eriocaulon intermedium Koernicke) and E. sollyanum are homologous with Eriocaulon trilobum (reportedly frequent in marshy wet fields).

This study was undertaken to explore the species of Eriocaulon from the rice fields of Bilaspur in Chhattisgarh.

\section{MATERIALS AND METHODS}

Extensive field visits were done on frequent intervals to survey the weed flora associated with rice fields in and around Bilaspur district in C.G. The species of Eriocaulon were collected and brought to the laboratory in polyethylene bags, washed and dried and their herbarium sheets were prepared.They were identified using the available flora, and their description has been done on their morphological and ecological aspects. The seed morphology characters have also been considered wherever necessary.

\section{RESULTS AND DISCUSSION}

Results are based on the keen observation and thorough analysis of the morphological characters and description of the species has been given on following lines: 


\section{Eriocaulon L}

Marshy or aquatic herbs usually perennial, with narrow grass like leaves but without a well-differentiated basal sheath. Very minute flowers in involucrate heads on a scape usually white or gray. Perianth in 2 worls. Sepals 2-3, free or connate, petals 2-3 or of hairs or 0 , often on the top of a stipe or slender corolla tube. Stamens 6 or fewer. Ovary 3, rarely 2-celled, stigma 3-2. Fruit aloculicidal capsule.

\section{Eriocaulon cinereum $\mathrm{R}$. $\mathrm{Br}$}

Annual scapigerous herbs. Leaves radical subulate or setaceous; acute 5-11 $\times 0.2-0.3 \mathrm{~cm}$. Scapes 3-12 cm long, heads terminal pale whitish, rarely purplish, and hemispherical 3-5 $\mathrm{mm}$ in diameter. Involucral bracts obtuse, passing to oblong-lanceolate floral bracts; flowers minute, unisexual, and monoecious; receptacle columner, glabrous or sparsely having male flowers: Calyx spathaceous, broadly spathulate, 3 toothed. Petals minute with an apical gland; stamens 6 anthers white, female flowers stipulate; sepals 1-2 hyaline or absent, petals absent. Ovaries stipulate 3-celled, stigmas 2-3. Capsules 3-lobed, membranous, loculicidal.

Flowering and fruiting - August to November.

Ecology- common in rice fields and in marshy places like edge of ponds.

\section{E. quinquangular $\mathrm{L}$}

Annual scapigerous herbs. Root stock absent, leaves radical, rosulate, linear or lanceolate, acuminate $5-10 \mathrm{~cm} \times 0.5 \mathrm{~cm}$; glabrous mostly turning into pale or deep purple on drying. Scapes 5-8 ridged upward, 7-15 cm long; involucral bracts sarious, linear oblong to broadly cuneate, straw colored, and glabrous.

Flowers minute, unisexual, monoecious, and male flowers: Subsessile, sepals 2-3, spathaceous, linear-oblanceolate, tips hairy, and petals minute hairy at apex with minute apical gland. Stamens 6, anthers black. Female flowers: Sepals 3, narrowly linear spathulate, hairy in the upper half, petals 3, free unequal oblanceolate (spathulate), and sparsely having not clawed with an apical black gland; ovary 3-celled, stipulate ovoid to globose, and style 3 fid. Capsule 3-lobed about $3 \mathrm{~mm}$. in diam. Seeds oblong or ovoid, $0.35 \mathrm{~mm} \times 0.25 \mathrm{~mm}$ pale purple.

Flowering and fruiting-September to April.

Ecology- common in paddy fields and muddy places (Figure 1).

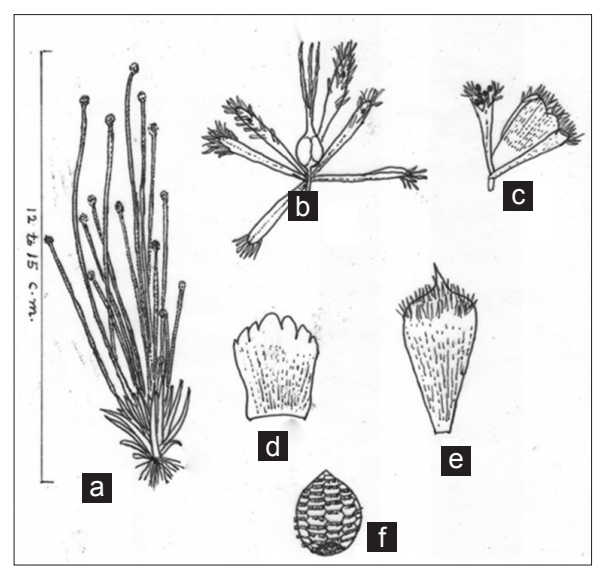

Figure 1: Eriocaulon quinquanulare L. (a) Plant habit, (b) female flower, (c) male flower, (d) gnoolucral bract, (e) floral bract, (f) seed. (All parts magnified five times of the original specimen)

\section{Eriocaulon martianum Wall Chex Koem}

Herbs, root stocks absent, leaves turning purple on drying. Leaves linear, acuminate, up to $9.5 \mathrm{~cm} \times 0.3$ $\mathrm{cm}$, globose. Sheaths up to $7 \mathrm{~cm}$ long, glabrous. Head hemispherical or globose, gray. Involucral bracts erect, elliptic, acute, glabrous, and straw colored. Floral bracts oblanceolate - cuneate, acuminate. Male flowers: Subsessile sepals, obovate into a spathe, 3-lobed with obtuse lobes, black. Petals 3, ovate hairy with a black gland. Anthers 6, dark brown. Female flowers: Subsessile, sepals 3, free, subequal, elliptic, flat glabrous black, petals 3, free subequal, spathulate, not clawed, obtuse, nearly $2 \mathrm{~mm}$ long, hyaline, sparse by long pilose without a black gland. Stipitate between sepals and petals. Ovary stalked obovoid, style 3 -fid. Seeds oblong to obovoid, approximately $0.40 \mathrm{~mm} \times 0.3 \mathrm{~mm}$, pale yellow.

Ecology - very rare in rice fields, especially at places where soil is sandy.

Flowering and fruiting-October to December.

\section{DISCUSSION AND CONCLUSION}

It was found that in E. quinquangular and E. martianum the color of the leaves and sheaths mostly turn into purplish on drying. In general leaves and sheaths do not provide much value for identification of the species. In E. cinereum in the shape and hairiness of receptacles are species. This could be noticed among different collections as suggested by Ansari and Balakrishnan (2009). However, this character may be used with other supporting characters may be used for delimiting the species of Eriocaulon.

However, E. setaceum synonymous to E. intermedium and E. sollyanum reported by Sharma et al. (1985) in 
Raipur could not be explored in Bilaspur. Ansari and Balakrishnan. (2009) opined that E. setaceum is restricted in its distribution to the western part of the India and Sri Lanka, whereas, E. sollyanum is homologous to E. trilobum which is frequent in marshy rice fields. However, this species could not be explored in this investigation.

\section{REFERENCES}

Ansari R, Balakrishnan NP. Family Eriocaulaceae in India. Revised Edition. Dehradun: Bishen Singh Mahendra Pal Singh; 2009.

Mishra DV. Ecological Studies of Some Common Weeds of Paddy Fields of Bilaspur, Ph.D. Thesis. Raipur: R.S. University; 1986.

Fyson PF. The Indian species of Eriocaulon. J Indian Bot 19191922;192-207, 259-266, 307-320, 3:112-18, 91-115.

Haines HH. The Botany of Bihar and Orisa. Vol. 5-6. London: Adlard \& West Newman; 1924. p. 1066-71.

Hooker JD. Eriocaulaceae-Flora of British India.Vol. 6. London: Reeve \& Co. Ltd.; 1893. p. 571-85.

Khanna KK, Kumar A, Jha AK. Floristic Diversity of Chhatisgarh (Angiosperms). Dehredun: Bishen Singh, Mahendrapal Singh; 2005.

Moldenke HN. A fifth summary of the Verbenaceae, Avicenniaceae, Stilbaceae, Dicrastylidaceae, Symphorenaceae, Nyctanthaceae and Eriocaulaceae of the world as to valid taxa, geographic distribution and synonymy. Vol. 1-2. New Jersey, USA: Food and Agriculture Organization; 1971.

Moldenke HN. A sixth summary of the Verbenaceae, Avicenniaceae, Stilbaceae, Dicrastylidaceae, Symphorenaceae, Nyctanthaceae and Eriocaulaceae of the world as to valid taxa, geographic distribution and synonymy. Phytologia Memoirs-II. New Jersey, USA: FAO; 1980.

Moldenke HN. A sixth summary of the Verbenaceae, Avicenniaceae, Stilbaceae, Chloanthaceae, Symphoremaceae, Nyctanthaceae, and Eriocaulaceae of the world as to valid taxa, geographic distribution and synonymy, supplement 1 . Phytologia 1982;50:233-70.

Moldenke HN. A sixth summary of the Verbenaceae, Avicenniaceae, Stilbaceae, Chloanthaceae, Symphoremaceae, Nyctanthaceae, and Eriocaulaceae of the world as to valid taxa, geographic distribution and synonymy, Supplement 2. Phytologia 1982a;52:110-29.

Moldenke HN. A sixth summary of the Verbenaceae, Avicenniaceae, Stilbaceae, Chloanthaceae, Symphoremaceae, Nyctanthaceae, and Eriocaulaceae of the world as to valid taxa, geographic distribution and synonymy, Supplement 4. Phytologia 1985;57:27-41.

Murti SK, Panigrahi G. BSI-flora of India series-3. Flora of Bilaspur District, M.P. Vol. 2. Calcutta: Botanical Survey of India; 1999. p. 656-9.

Nair RV. Taxonomic significance of seed coat morphology in Ericaulon Linn. (Eriocaulaceae). Seed Sci Technol 1987;15:247-310.

Ruhland W. Eriocaulaceae. In: Engler A, editor. Das Pflanzenreich, Regni Vegetabilis Conspectus 4 heft 30. Leipzig: Wilhelm Engelmann.

Sharma H, SharmaVB, Das RD. Flora of Raipur and its environs. In: Botanical Researches from Chhattisgarh-Chhattisgarh Botanical Association. Raipur (M.P.), India: Department of Bio-Science, Ravi Shankar University; 1985. 